\title{
The Necessity of a War Chest in This Country, or a Greatly Increased Gold Reserve
}

\author{
Sir Robert Giffen K.C.B., LL.D., F.R.S.
}

To cite this article: Sir Robert Giffen K.C.B., LL.D., F.R.S. (1908) The Necessity of a War Chest in This Country, or a Greatly Increased Gold Reserve, Royal United Services Institution. Journal, 52:368, 1329-1353, DOI: 10.1080/03071840809418923

To link to this article: http://dx.doi.org/10.1080/03071840809418923

\section{曲 Published online: 11 Sep 2009.}

Submit your article to this journal

Џll Article views: 5

Q View related articles ¿ 


\section{THE NECESSITY OF A WAR CHES'I IN THIS}

COUNTRY, OR A GREATLY INCREASED GOLD RESERVE.

By Sir ROBERT GIFFEN, K.C.B., LL.D., F.R.S.

On Wednesday, 25th March, 1908.

Sir Felix Schuster, Bart., Member of the Council of India and

President and Chairman of the Council of the Institute of Bankers, in the Chair.

WHAT has been in my mind in taking up this subject is not the whole question of war chests which belong strictly to the domain of the military and naval expert, viz.: What kind of chest to provide for particular operations, and how? In ordinary times, for modern civilised Governments, which as far as war is concerned, have mainly to do with wars of "limited liability," as they have been aptly called, the arrangements for a military chest are a mere departmental detail of administration.

Even in a comparatively serious war, where the whole expenditure may be large enough to affect the national finances, a war like our own South African war the other day, the mode and means of replenishing the military chest as the war goes on may not be at all a difficult matter, the monetary machinery of the modern State being generally so good.

I desire also to avoid the subject of a special cash reserve to be used in carrying on some war in which the State may be engaged, such as was instituted in Prussia, and which still exists in some form, though it does not seem to have increased of recent years beyond the $\$ 6,000,000$ at which it was long ago fixed. A reserve of this sort could have made little difference to the Franco-German war, with its enormous outlay, or to any war on a modern scale, such as that between Japan and Russia. Such a reserve may be useful for certain purposes, but could hardly aid directly to a material extent in a formidable contest.

What I desire to bring before you is something different: the difficulty that may and must arise among the leading States should they become engaged in war with each other in a measure that jeopardises the mechanism of credit in the States affected, and throughout the commercial world generally. It appears to me that this is a formidable possibility of the international credit system that has never been adequately considered. And it has not been considered for the simple reason that as a matter 
of fact since this system became developed in its modern proportions there has been no war in which the leading nations most important to the system have been mutually involved. The credit system in its full development internationally, with bankers' clearing houses, a general currency. of cheques, and a heirarchy of banks dominated, in this country especially, by a single great reserve bank at the top, has lasted little more than half or threequarters of a century in this country and in Germany, the United States, France, and other countries even less: In all this time there has been no war-that is, to be quite accurate, no war of "unlimited liability"-involving most of the leading nations at once, more especially involving the State which possesses the citadel of the credit system-our own. There have doubtless been some most serious wars which disturbed credit more or less-the United States Civil War in $1861-5$, the Austro-Prussian war in 1866 , the Franco-German war in $1870-$ $7 \mathrm{I}$, the Russo-Turkish war in 1878 , the Spanish-American war, and the Russo-Japanese war; but in none of these was the working of the international credit system substantially endangered, while our own country-the citadel of the credit system-was fortunately not engaged. We are considering, then, a kind of war of which there has been no real experience, though some of the happenings in the less serious wars referred to were of a nature to excite no small alarm. 'If these things have been done in the green tree, what shall not be done in the dry?

What would happen now if, for instance, France and Germany, with their allies, were to be again at war, or if the United States and Japan, plus a great European Power, were to be embroiled? Or if absit omen this country were itself to be engaged with Germany or the United States, or Russia, with perhaps one or two more States joining in as our allies or enemies? Such a war, it seems to me, would bring upon us, as well as upon the whole community of civilised States to which the system of international credit extends, quite unprecedented calamities and dangers. This would result from the breakdown of the credit system itself and the interruption of international commerce. In past times great injuries to such commerce as existed were due to these causes. One need only refer for illustration to the anticipated effects on the Highland clans of the failure of the house of Osbaldiston, described in Sir Walter Scott's novel of "Rob Roy," and the reaction of a Highland rising on the business and credit of London itself. But nowadays there would be vast indirect as well as direct effects if any important factors in the international circle were to be displaced, still more if two or three great commercial communities were affected by a general suspension of payments. Such and no less are the evils to be anticipated from a breakdown of the international system of credit. The other evils of great warsthe exhaustion of resources, with loss of life, disease, and misery-would remain what they have already been, but in addition there would be these new and formidable evils. 
To make the impression more definite we may classify the. mischiefs to be anticipated from the outbreak of great wars affecting the leading civilised States. I would mention first of all the stoppage or great contraction of the volume of imports and exports between enemy States and the States dependent on them. Between States actually at war with each other there would of course be stoppage and contraction affecting, as between this country and the United States alone, if we should be at war a direct import of 136 million pounds ${ }^{1}$ annually into this country, and a direct export of 60 million pounds, ${ }^{2}$ besides 13 million pounds imports and 18 million pounds exports of gold and silver, and an indirect trade of about equal amount in imports from third countries into the United States and exports from the United Kingdom to those third countries which have their ultimate origin in the direct trade. But the stoppage and contraction would extend yet further, the customers of all the countries primarily affected being unable to escape the effect of the losses of those countries. $\therefore$ The commotion in the whole banking world would be something quite unexampled. "Every month, every week, every day, bills are coming due in the great centres and especially in London, which cannot be met if the regularity of trade is interfered with. A merchant, in order to meet a bill coming due, relies on his ability to discount a new bill against goods to arrive, and when neither goods nor bill are received he must fall back on reserves, which it has not been the practice to maintain. Interruption of the regularity of trade means, accordingly, widespread ruin to merchants and bankers together.

Next, there would be a run for cash and withdrawal of deposits from banks which would also tend to bring about general failure and bankruptcy. Such a run for cash might be occasioned by the stoppage and contraction of the foreign trade itself; but apart from that there might easily be a general alarm among the depositors of banks on the outbreak of a great war as to the safety of their deposits, especially if this country should be involved. No one denies the possibility of raids on the United Kingdom in the event of a great naval conflict, even if there is no possibility, as some contend, of a serious invasion; but what would be the view of depositors were any raids to be actually reported, however small? The funds fell in 1797 , when a few Frenchmen, who were soon disposed of, landed on the Welsh coast, and something far more serious might easily be attempted. Naval movements of a formidable kind might also be threatened, so that in the first days of war all our old feeling of security against war's alarms as affecting ourselves might vanish. What the result would be was seen in Germany and

1 Including the Philippino Islands.

2 Including. Foreign and Colonial as well as British produce aad manufactures. 
France at the outbreak of the war of 1870 , when every bank on the Continent prepared against a run and withdrew its money from London to meet the alarm. Clearly there might again be a run on this country in the more serious contingency described, and foreign "depositors might take the view that an invasion of this country and a wide interruption of our communications are more on the cards than we comfortably take for granted. In 1870, after the first run. upon London for cash, money came back from Continental bankers to London, and the subsequent steadiness of the London money market all through the war mitigated the disturbance of credit on the Continent. But would money come back to London if we should be involved in a doubtful war with possibilities of defeat and invasion?

On the nature and effects of a great banking panic there is no need to enlarge. Apart from the miseries resulting to depositors and shareholders, who are suddenly impoverished, there is no more potent cause of widespread bankruptcy and unemployment.

The general apprehensions and troubles that would arise from extensive want of employment constitute another kind of mischief, whether the want of employment is due to direct stoppage of trade or to a banking panic or to both causes combined. It is difficult to realise the magnitude of the evil it may be necessary to deal with, and especially the extent of the civil tumults that may occur. We have had little experience of civil tumult for generations, but as late as the thirties and forties of last century there were lamentable incidents. It is within my own recollection that in 1849 bread riots were suppressed in Glasgow by the Yeomaniy, not without loss of life. All these tumults would further help to strain credit to the utmost and intensify the banking panic itself.

In this way, then we arrive at the question of the sufficiency of the cash reserve of our credit system in the contingency of the outbreak of a really great war-a war with "unlimited liability." This is not, of course, the only circumstance of our economic condition which the public and the Government should consider beforehand, but it is obviously of special importance, as disturbance of credit would produce or aggravate other mischiefs. Are our present cash reserve arrangements, then, having in view the contingency of a great war, adequate or not?

Investigating this problem we are met at the outset by the suggestion that no preparation can be adequate-that whatever we do the confusion at the outbreak of a great war will be indescribable, and the Government could hardly do anything but order a general suspension of specie payments, as was done in 1797, until the country adjusted itself to the new conditions. It is, indeed, much to be feared that something of this sort may happen. But less inadequate preparations than are at present made may nevertheless be useful. The possibility of avoiding a resort to inconvertible paper is surely worth aiming at. It 
was the opinion of good city authorities at the time of the American Civil War that the resort by the Federal Government to vast issues of inconvertible paper might have been avoided, not only with great economy in the conduct of the war itself, but with advantages of political prestige and credit which would have been most material.

Broadly speaking, then, the main facts as to our cash reserves are these :-

1. The liabilities of our banking system may be put at 9 ro million pounds at least, this being the total of the deposits in the banks of the United Kingdom, including the Bank of England. (See "Economist Supplement,"? 22nd February, 1908, p. 5I.) I believe the real figure ought to be larger so as to include those of Continental and Colonial banks which keep their reserves in London, and to some extent United States banks which also use London as a reserve centre ; there is also a potential liability beyond the figure of actual deposits at any moment owing to the privilege of a banker's customers - a reserve banker's customers especially to borrow in times of emergency. Making all allowance:for duplicate liabilities arising from one banker's liability being to another banker, we cannot reduce substantially the round figure of 900 million pounds.

i. Against this vast liability of close upon a thousand millions or more, there is almost literaliy no provision except the banking reserve of the Bank of England, about 20 to 25 million pounds in recent times. This was explained many. years ago by Mr.'Bagehot, in his well-known book, "Lombard Street, which happens to be still up-to-date, as there has been no great improvement since, and in recent days our Chairman, amorig others, has dealt with the topic.r: Practically it may be admitted that the whole stock' of bullion in the Bank of England; the amount held against the note issues as well as the banking' reserve proper, may be available as a reserve, which would raise the figure from about 20. millions or 25 millions to about 40 million pounds; but there is hardly anything else except, may be, the 12 or is million pounds hield in Scotland and Ireland against the note issues of the Scotch and Irish banks.

It will be said perhaps that the coin in other banks should be included, as it "will be available pro tanto against a run ; but the sums, whatever "they. are, are obviously rather till money, required in the daily outgo and incoming of the business, and could not really be parted with in an emergency. As a matter of fact, they are not usually shown separately in bank accounts, being mixed up with cash at call or in the Bank of England.

It appears at first sight so extraordinary that the banks of the United Kingdom should generally keep no cash reserve in their own hands, that in speaking to a non-banking audience I may be excused for referring, however briefly, to the accounts of different banks to show how their reserves; which are no doubt mostly mọre than adequate, looking at them individually; consiśt mainly of cash at call; that is, on deposit with other banks, 
or cash at the Bank of England or securities. I shall mention no names; as that might be invidious; and is quite unnecessary for the present purpose.

Let me take first a Scotch bank (A) which happens to come before me as I write. The liabilities of the bank to the public are stated to be $£_{14}, 54 \mathrm{I}, 000$, and the assets of cash and easily available securities are described as follows:-

Gold and silver coin, notes of other banks, cash balances with London bankers, and money at call or short notice in London ... $\quad \ldots \quad \ldots \quad 2,779,000$.

$2 \frac{1}{2}$ per cent. Consols; etc. $\quad \ldots \quad \ldots \quad$ 1,852,000

Stock in Bank of England, Corporation,

Railway Debenture, and other stocks

$$
\cdots \frac{2,524,000}{E_{7}, 155,000}
$$

This is no doubt a very good showing, as far as individual banking:goes, as liabilities of 14 million pounds to the public are half covered by cash in hand or at call and easily available securities; but clearly such assets, even the cash so-called, which consists partly of notes of other banks, balances with London bankers, and money at call or short notice in London depend largely on the London bankers, and through them on the Bank of England. There is no contribution here to the general emergency reserve of the country-a reserve for occasions, when every bank is pressed.

Let us take next one of the great London banks (B). Here the liabilities to the public, including four million pounds of bills accepted or endorsed, amount to no less a sum than $£ 69,280,000$, and the cash assets are described as follows :-

Cash in hand and with Bank of

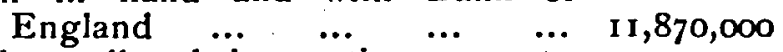

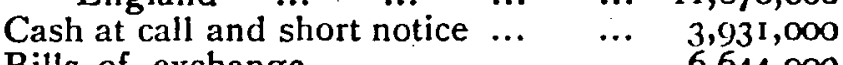

Bills of exchange $\quad \ldots \quad \ldots \quad \ldots, \quad \ldots, 644,000$

Consols, etc. $\ldots \quad \ldots \quad \ldots \quad \ldots \quad 5,927,000$

Indian and Colonial Government

securities, etc. $\quad \ldots \quad \ldots \quad \ldots \quad 4,867,000$

$£ 33,239,000$

-again a sum in cash or the assumed equivalent amounting to nearly half the liabilities to the public. But the cash proper - that is, cash in hand and with the Bank of England, the absolutely unemployed cash as far as the bank is concerned-is only about one-third of the total. All the rest is dependent on other institutions and the normal working of the market in Lombard Street. ' In one respect the account is an improvement on A, the cash in hand and at the Bank of England being distinguished from money with other banks or money at call or 
short notice; but how much is really in the bank's own hands, and especially how much that is not till money, we are not told.

Let us carry the matter a step further. Nention is made in these accounts, $A$ and $B$, which are fair specimens of the country and London banks, of money with London bankers and money at call or short notice. What I propose now to look at are balance-sheets of London banks belonging to the special class of discount houses which are used by other banks as places for depositing money at call or short notice. One of these, which I shall call $C$, shows a liability of $£ 24,673,000$ to the public, and describes its "cash" as follows:-

$\begin{array}{llllll}\text { Cash at bankers } & \ldots & \ldots & \ldots & \ldots & 1,062,000\end{array}$

Consols, etc. $\quad \ldots \quad \ldots \quad \ldots \quad \ldots \quad \ldots .2,494,000$

Loans at call and short notice $\quad \ldots \quad 1,305,000$

$6 \longdiv { 4 , 8 6 1 , 0 0 0 }$

-again a good showing with the money market generally in a normal condition, but, with no independent "caslı": for an emergency. Another $I$ shall call $D$ shows liabilities of E16,804,000, and its "cash" as follows:-

$\begin{array}{lcccccr}\text { Cash } & \ldots & \ldots & \ldots & \ldots & \ldots & 259,000 \\ \text { Securities } \ldots & \ldots & \ldots & \ldots & \ldots & 2,125,000 \\ \text { Loans at call, short and fixed dates } & \ldots & 998,000 \\ & & & £ 3,382,000\end{array}$

-on which the same remarks may be made as on $C$. The point is, that these bankers' banks, with which to some extent country and London bankers keep their money on deposit, do not themselves keep idle cash in reserve to any extent, but are dependent on the normal working of the market and on the Bank of England.

Thus the conclusion is supported that the only emergency reserve in our credit system is that of the Bank of England. The display of cash at call or short notice, mixed up with cash in hand and at the Bank of England, is found to be generally a display of no cash at all for purposes such as we are considering. There is practically no reserve but the 40 or 50 millions at the outside which can be made up at the Bank of England, with such additions as might be possible in an emergency by the diversion of the amounts held against their note issues by the Scotch and Irish banks.

We have only to look at what has happened elsewhere to see how inadequate the amounts stated are. In the recent panic in America the banks started with about 200 million pounds cash (specie and legal tenders) against 2,500 million pounds of liabilities, or about 8 per cent., and how speedily they were bowled over we all know. A run began which no bank could face. Even in this country, I suppose, the Black Friday of Overends in 1866 is not quite forgotten, when the reserve of the 
Bank of England, as large in proportion then as now, was all but emptied in a day. More recently, in 1878 , the circulation of the Bank of England, owing to the drain of money to the country caused by discredit, increased about 15 million pounds in two months; and still more recently, at the time of the Baring crisis in 1890 , special measures were needed to prevent the outbreak of panic. A fortiori, then, should a great war break out and business be widely interrupted, the demands upon English banks, quite apart from panic at first, might easily become overwhelming, and the paltry 25 million or 40 million pounds, or say 50 million pounds, which is all we have to show, would dwindle to nothing in a day or two." Hitherto at times our system has been exposed to great dangers by exclusively foreign military events-the Civil War in the United States, the Austro-Prussian War in I866; and the Franco-German War in 1870-71, all of which did no small mischief to our credit system; but an occasion threatening ourselves would have tenfold danger.

It will be urged, perhaps, that it is not fair to compare our banking liabilities with those in other credit systems, which may be more subject to panic. In America, it may be said, and in this country at former periods; a.larger proportion of deposits with banks was composed of savings by the general public than is now the case, when the deposits are more largely the balances of current accounts required daily. in business transactions or belong to institutions and companies associated with the banks themselves, and otherwise not subject to panic like the uneducated miscellaneous depositor. There is no doubt some truth in this. But possibly a minute analysis of the deposits might also show that other changes which have occurred are not so favourable, that we are more liable to be affected now by 'large demands of a legitimate kind than was formerly the case, and that there are miscellaneous deposits of a quite sufficient amount to become the subject of an alarming run if our margin is too small.

It is sometimes said, also, that a narrow comparison of banking cash ass'ets and Tiabilities, such as has just been made, doés not táke sufficiently into account the firmness and elasticity of our banking system, the solidity of the credit that has come to be established, and the prudence of our banks in their individual capacity, along with the fewness of their numbers, compared with what was the case at any former period or in the United States at the present day. "This would hardly be the place to discuss such questions in detail, and it is the less necessary for me to do so, as our Chairman has distinguished himself by their discussion in banking circles themselves. But granting all that may be said on this head, we must recognise that a credit system which is constructed against ordinary dangers and which may serve fairly well in quiet times or in meeting the ordinary oscillations of business, which is equal to a breaking strain, to employ an engineering phrase, with which a bank reserve of 50 million pounds is sufficient to cope, 
may be destroyed by a strain which wou'd require 100 million pounds or more. Once the breaking point is reached the edifice goes. . The figures I have already cited amply show that this general prudence is quite consistent with the neglect of individual banks to provide such a reserve against emergencies as would be available in a breakdown of the system itself owing to what we may call an external blizzard.

The conclusion; then, is that the banking position in this country is one of real danger in the event of a great war-a war, to emphasise the point made at the beginning, with unlimited liability: The question is, of course, primarily for the banking community itself, and for the chief customers associated with them, who would act wisely in taking an active interest in the subject; yet if the Government can do anything by way of co-operation or otherwise, surely there is occasion for its intervention. Great economic disorders at the outbreak of a war or when war is threatened may hamper the political and diplomatic action of the Government and impede the direction of our naval and military forces. Instead of attending to the business of the war itself, the Government may have its hands tied by questions of unemployment and civil tumults, and may have to face all at once and with no preparation the dilemma of issuing inconvertible paper. To have a banking system so strong as to go on unshaken in the face of a great international upheaval would be worth a considerable price.

What; then, can the Government do? and what ought it to do in time of peace, when the matter can be quietly taken in hand?

One suggestion that occurs to me must, I believe, be put aside. This is, that the Government should itself accumulate a considerable sum in cash for a rainy day, which can be used to assist in preserving credit at the outbreak of a great war. The difficulty would be that any such sum under the immediate control of the Government of the day, before it could be of service, would have to be placed in the hands of bankers and lent out, and there might be political and even military objections to such a course-objections based upon considerations of the same nature as those which induced the Government in 197 to restrict the Bank of England from paying in specie. When hostile Governments are competing for the possession of bullion no one of them can be expected to have the fortitude to part with its own special stock, if it has one, although this might be the wisest course." If the Government is to keep a war reserve in time of peace at all it can only be on the pirinciples and for the purposes with which the Geirman war chest is maintained.

What the Government, it seems to me, can do is perhaps to take such measures with its own banking arrangements as will enable the Bank of England in time of peace and quiet to add to its normal reserve. The Government even now, I am inclined to believe, considering the amount of its transactions,

VOL. LII. $4 \mathrm{~N}$ 
and the various privileges it confers on the Bank of England, keeps with that institution what any ordinary bank would decm an adequate cash balance. According to a recent weekly account before me, the public deposits with the Bank of England -substantially the cash balances of the Government in all its departments-amount to no less a sum than over 15 million pounds, and the figure is frequently : larger. This is a considerable sum for a customer whose average weckly income and outgo is three millions, and which is tolerably regular in. its operations, although like other customers it accumulates money at one season and disperses it at another. But in spite of this favourable showing for the Government, tried by ordinary tests, what has to be considered is the public advantage, and in this view what $I$ suggest is that the Government should not look on itself as a customer in the ordinary way, but should take advantage of its special relation with the Bank of: England to encourage and strengthen that institution in the task of maintaining a banking reserve. As to. what additions the Bank of England ought to make, what assistance it should invite the Government to give, and what steps both together should urge upon the customers of the Bank, it would be premature to speak in detail. In an unofficial position I am not prepared to go into the question fully: It would clearly be reasonable, however, that the Government, in negotiating with the Bank of England as to what payment is to be made for the annual service of the debt and for other services rendered by the Bank, and what payment, on the other hand, is to be made by the Bank to the Government for the privilege of note issue against securities, ought to arrange in some way that the expense of the maintenance of a reserve for the public benefit, to be employed in times of emergency, is to be regarded pro tanto as a service rendered to the State. In other words, the question of the banking reserve ought to be regarded as of the essence of the whole contract between the Government and the Bank.

My own impression is that the result of any study of the question from this point of view will be that the Government will either increase its payment to the Bank for services rendered or will forego part of the sum it: now receives for the privilege of note issue; but in return the Bank will undertake to keep a larger reserve-say so million pounds more than are now kept on the average-for emergencies. A hard and fast written contract on this head is not in question, seeing that the reserve has occasionally to be used.' 'But both the Government and the Bank of England can be trusted in such a matter, the principle being once accepted, to establish and maintain an honourable understanding after the fashion with which the guarantee of the various banks to the Bank of England, which was said not to he legally binding, was given and adhered to at the time of the Baring crisis.

Once the Bank of England had come to such an understanding with the Government, it would be in a position, on 
the other side, to negotiate with the joint stock and private banks on the same subject. The latter are in a difficulty at present, as there is no agreement or understanding, I believe, with the Bank of England as to the amount of their cash balance the Bank in ordinary times is to maintain in cash; but the arrangement with the Government might furnish a model to be followed, not slavishly, of course, but with suitable modifications.

But apart from particular suggestions the point of the Government interest ought not to be lost sight of. It is supremely interested, and it should not let itself be surprised by events. There will be plenty to think of at the outbreak of a war, even if the banking position should be strong and not weak.

Apart from any action -which the Government, the Bank of England, and other banks may take, it is to be hoped that the general discussion of the subject will not be without its uses. The root of the evil appears on analysis to be largely individual, and an abuse of the theory on which deposit banking is founded. It is advantageous for the individual to deposit one's funds in a bank, primarily for security and secondarily for the interest and other advantages banks have found it expedient to give, so that customers instead of paying a bank to keep money for them, which was the way banking began, receive payment for making their deposits. But what has happened is that Englishmen have overdone their trust in banking. They rely on their bank to pull them through an emergency and keep their normal balance with the banker at too low a level, thereby incurring great danger when an emergency does occur, and weakening the power of the banker in his turn to maintain a cash reserve. Next, the value of the interest obtainable on deposits is exaggerated, and the banker, having to pay interest to attract and keep the deposits, is further crippled in the necessary function of keeping a reserve of idle cash. Quite apart from bankers, therefore, business people have to learn the expediency of not using their floating money up to the hilt, but of keeping something in reserve. I have heard it said by more than one successful business man that one reason of their success was their ample provision of cash for an emergency, so that they could not be taken aback. The rule, of course, should be moderation in all things; but the problems of our banking system would certainly be easier if it were the habit of everybody as well as bankers to keep a larger proportion of their means in liquid form than they do. We shall be lucky if the lesson is learnt without the great war which will surely bring it home.

Mr. Srexser Wilkinson :-It appears to me that in his paper to-day, Sir Robert Giffen has shown the very greatest judgment, not so much in his statement of the case and of the necessity for particular measures, but in the very great moderation of the proposals he makes with regard to so difficult a matter. I do not feel competent, as a person without any 
financial experience, to discuss proposals for a solution; it would be very difficult to go beyond the general suggestions made by Sir Robert Giffen, namely, that the Bank of England in particular and the other banks and private individuals should further develop the practice of keeping a reserve. I for one do not see how it would be possible to go much beyond that, although I should agree, as far as I understand it, with Sir Robert Giffen's proposal, that the Government should use its influence, as: far as possible, to assist the bank in that direction. But I should like to be allowed to make one or two remarks on certain points. First of all, Sir Robert Giffen uses a phrase which has been occasionally used of late years, " Vars of limited liability.". I think there is a danger of its being misleading. It is based on a distinction which was drawn by Clausewitz in his "Theory of War "; but Clausewitz did not mear by. that to suggest that wars should be roughly divided into two classes, wars which were dangerous, and wars which were not-those in which you risk everything, and those in which you do not. It was a historical description. He based his theory on the experience of his own lifetime, the experience of the wars of the Revolution, and as he tried to expand his theory by the study of previous wars, he was struck by the great difference in character between those wars of the $17^{\text {th }}$ and 18 th century, of "which he examined the history, and the wars of his own experience; and he pointed out that a great change had come over the character of war in consequence of what may be called its nationalisation; in consequence of that which took place, first in France during the Revolution, and afterwards in the other countries opposed. to France, namely, that the war became a national affair, carried on with the whole resources of the nation. He laid it down that a war of that sort was a struggle for existence, and that the wars that had been previously waged-dynastic nars, carried on with small standing armies-could not bring about anything like the same kind of risks. Clausewitz raised the question whether all future wars, would have the character of struggles for existence, such as had belonged to the wars against the French Empire; but subsequent students of history have almost unanimously agreed that the earlier kind of war is very unlikely to recur, and since Clausewitz's time wars between great States have always borne the character of unlimited liability: The matter just now seems of importance. The distinction has been erroneously used by some recent writers, who, it appears to me, have not understood the theory of Clausewitz. I see on my right and left Colonel Maude and Major Stewart Murray. If any men in England know Clausewitz's theory it will be these two gentlemen, and 1 hope they will support me and find themselves in agrecment with me on that point. . The subject which Sir Robert Giffer has brought before us comes under the general head of surprise in wat The greatest source of weakness in war is when one side or the other is taken by surprise. A surprise consists in this : that you have to meet a state of circumstances that you did not foresee, and, therefore, I hold that the greatest service is done to us by Sir Robert Giffen in calling. our attention to this particular point about the gold reserve: But there are three respects in which surprise is likely to occur in this country. The first is that of the gold reserve; the second is that of the food reserve; and the third is that of unemployment. I think the danger of unemployment is not so great as is imagined, because in a serious war it will be absolutely necessary to call out all the reserves and to strengthen the forces in every possible way, and thus a very large number of men will necessarily pass into the army in one shape or another, and their disappearance from the labour market will relieve the strain of unemployment. 
When you get half a million or even a million men in Government service and Government pay as soldiers in one form or another, you will certainly relieve the pressure in that direction. The second danger of surprise is that immediately on the outbreak of a serious war, certainly within a wcels, people will awaken to the fact that this country has a limited food supply, and you will have a run on the food supply in the same way that you will have a run on the gold reserves. Sir Robert. Giffen referred to the Prussian Fund, which is kept in gold in Berlin. I think that fund was for quite a different purpose than the purpose Sir Robert fiffen has in view. His object is to do something to preveat the credit system collapsing on the outbreak of war, and I am inclined to think, and have long becn inclined to think, that nothing you can do will prevent that, because the credit system is so great, and the liability so great, and the reserve you have so small, and the possibility of increasing it so slight, that I doubt whether anything you can do will prevent a suspension of payment or some collapse of that sort shortly after the beginning of a war. But I understand that the Prussian Fund is not at all for the purpose of propping up credit, but simply and solely to be used for the mobilisation of the very large forces which Prussia would put into the field. I should like to suggest a different sort of precaution to a merely financial one. After all, this appears to me very largely a matter of the Navy. I remember, a. good many years ago, when I had occasion to write about the Navy, and think a good deal about the case of a British war, it seemed to me that a British war could be classed in three ways. Either you are going to have a war in which from the beginning you will command the sea, or you will have a war in which you start with having to fight for the command of the sea and eventually secure it, or you will have a war in which you will lose the command of the sea. In the third case; if you lose the command of the sea you lose everything. In the first case, if you start out with it and keep it, I believe you will be moderately secure, and that then, and then only, you might keep up internal credit. But in a war in which at the beginning you have not got command of the sea', it appears to me that you are bound to begin with a very great panic, with an Overend and Gurney panic, and a Lancashire cotton famine rolled into one; and the soundest precaution against that is to take care that the Navy is in order; by which I mean not so much kept at a given numerical standard, although I hold a high numerical standard to be requisite, but that its administration, its organisation, its discipline, and its training shall be as good as they can be.

Major S. L. Murkay (late Gordon Highlanders):-I associate myself with the remarks made by Mr. Spenser Wilkinson, especially with those in which he referred to the great master-work of Clausewitz, "On War," of which he has, I know, made a lifelong study. It is with regret that I find myself called upon to speak, for with such a subject and such a lecturer this room should have been full of speakers far better acquainted with banking matters than I am. Their absence is much to be regretted, especially as one know's that the necessity of a larger gold reserve has been much discussed of recent years in banking circles. It is impossible to over-cstimate the importance of this subject, which has been so ably brought before us to-day. And the weight which attaches itself to any utterarice of Sir Robert Giffen, makes the warning he has given us more significant, or perhaps I should say, more ominous. I have myself long taken such an interest in this subject as one unacquainted with the details of banking can do, for it is obvious that if our monetary system, our 
credit system, be not based on a foundation sufficiently strong and solid to stand the cmergency of a great European war, then our edifice of Imperial Defence is built upon sand. That is plain. It is noteworthy that last week the German Chancellor was asked in the German Parliament if he would not release into circulation the millions lorked up in the German war chest? 'His answer was, that most certainly he would not, because war might come at a time of financial crisis, which shows that foreign Statesmen do not neglect this question of International credit which has been brought before us to-day, but are well aware of its gravity.: It also follows that they. will be well aware of the possibility of so manipulating that system of International credit as to embarrass or weaken a hostile Power just before or at the declaration of war. That, I think, we may take for granted. In the few minutes which are available I will only endeavour to deal with one or two points in this very able lecture, which I should like to emphasise.: The lecturer refers to the necessity of the maintenance of our credit system during a European war, because, as he says, "there is no more potent cause of widespread bankruptcy and unemployment than a banking panic." Also he says: "It is difficult to realise the magnitude of the evil it may be necessary to deal with, and especially the extent of the civil tumults that may occur." Here we touch the great question of the preservation in a modern industrial democratic state of internal peace during external war. This is a matter to which I have given much study, for I believe that it is of much greater importance, and contains much greater dangers, than most people imagine. Since our last great war-the Napoleonic-the whole life, the whole nature, of the European nations has changed. And the whole system of warfare has changed to a degree quite unrealised by the majority of our countrymen, who cannot be made to understand that to-day every modern nation makes war as a nation-in-arms. with the whole concentrated force of its manhood, physical and intellectual. The vast forces thus called into play render costly preparation on an cqually vast scale absolutely necessary, and thus renders the money question more than ever paramount. And the means of exhausting, or weakening, the money power or credit of an adversary, manifestly has consequently : become a warlike operation of the first importance, such as causing a drain of gold from the hostile nation by a financial crisis arranged just before or at the outbreak of war, for which contingency the Germani war chest is kept. It is a contingency we should also keep in mind and prepare for. The great difficulty which cach of the great modern industrial nations will have to face in a great war is that of providing atork and bread for their industrial millions of toilers during the war. Work and bread each State must provide, or face the alternative, an outbreak of the volcanic forces $w$ hich everywhere underlie democracy. France, after the Franco-German War; Russia, after the Russo-Japanese. War, are cases in point; many more might be added, but there is not time available. An as instance of a modern crowd, consider the crowd at the declaration of the Poll at Peckham on 24th March, estimated at nearly one million strong: Consider if, during war, that crowd were without work or bread; imagine if that crowd were concentrated round Westminster!. I will not pursue the subject. It may be laid down that a proper organisation of a modern industrial nation for war should consist of two distinct systems of organisation :-(a) External, or naval and military operations, aiming at the overthrow and disarmament of the eneny; (b) Internal organisation for war, to insure the certainty of work and bread for the millions of toilers, of voters. Under intern.1 organisation come three great divisions, equally important parts of the 
same whole, which should be considered and worked together to the desired end of eternal peace. They are:-(1) Our monetary system, our credit system, as the necessary factor in all our trade, business, employment, wages; (2) Our commerce protection, the materials and products of industry, the channel of wages; (3) Our food supply; that the war-price thereof shall not place food beyond the reach of the $7,000,000$ or so of our poorest. All these three are the component parts of the great problem. which we have to solve (for we have not done it yet) of how to insure work and bread for our industrial millions in a European war. Each of these three has got to be put upon a footing that will stand the emergency of a great war. The solution of each will be a great step forkard. That is one reason why I weicome this lecture, and hope that it will bear good fruit. For what 1 have called the external organisation, the naval and military part, the soldiers and sailors have done, and are doing, their best, though terribly hampered by Parliamentary politicians, who do not understand, who know nothing about modern war. As regards the internal organisation for war, the gold or credit supply, the commerce protection, the food supply, the soldiers and sailors can do nothing, for the country does not listen to them. Civilians only can do it, and should do it, and must do it, unless they wish to see our race go under in the next great struggle when it comes. I hope, therefore, that this matter of our monetary system, our credit system, will not be allowed to drop, but that some association will be formed in the City to press it forward. It should not be allowed to drop. I hope that it never will be allowed to drop. There is one more point I would like to make. It is this:-The amount of money which the country will have to find for a great war will be stupendous; far greater than most people imagine. Consider for a moment the case of one.possible hostile alliance, Germany and Russia, say; twenty years hence. Germany with her new navy ready at last will threaten us in the North Sea; Russia, reformed, re-organised, more formidable than ever; will move $5 \infty, 000$ men on to Afghanistan. Such a war cannot be put at less than $£_{250,000,000}$ or $£_{300,000,000}$ a year for two at least, or perhaps three, years, $i . e .$, a possible $\mathcal{E}_{750}, 000,000$ or $\mathcal{L} 900,000,000$ before it is finished. So it seems, taking all things into rough account. And if, through neglect of adequate preparation beforehand, through false economy beforehand, we fail, then in addition to our own enormous war expenses we shall have to pay as war indemnity those of the cnemy. Such a war indemnity would absolutely ruin our trade for a generation or more. It is worth some sacrifice--the money and organisation, external and internal, of adequate preparations-to avoid. It can only be avoided if the civilians take their share of the preparations. As their special present share I would urge the industrial or internal organisation of the United Kingdom for war, towards which this lecture tends as a most valuable contribution.

Colonel F. N: MaUde, C.B., late Commanding Hampshire R.E. Vols. (late R.E.) :-By the merest accident $I$ find myself this afternoon shoulder to shoulder with my friends, Mr. Spenser WWilkinson and Major Stewart Murray, who have anticipated many remarks I was going to make, more particularly everything about Clausewitz. The distinction Mr. Spenser Wilkinson has drawn between the war of limited liability and the war of unlimited liability is historically correct. Clausewitz had not in his mind at the time any question of the use of the word "liability" in its modern sense. Clausewitz was a prophet when it came to a question of war, and he foresaw, far in advance of his time, what that unlimited use of force which he always advocated must bring about. His principle 
was that "in war the use of force is absolute," and any attempt to hinder its development was quite out of the question and false philanthropy. Following from that, he did not define his "force" as merely "force relating to the use of weapons in the field," but he meant any kind of force which would induce the enemy to bow to your will. It is not necessary to form troops up in line of battle and shoot at each other. If you can compel the Power you are at war with to do what you want without recourse to absolute physical contact, there is no reason why you should not do so, particularly if that happens to be the cheapest and simplest way. Following that idea out, this is the attitude of mind with which the Great General Staffs of several countries on the Continent view it. They do not consider it necessary to go to actual fighting if they can, by the creation of a gold panic or other equally effective means, so thoroughly paralyse the enemy's vitality that the organisation for defence will no longer work. In that way they have gained all they wish to gain without the trouble and expense of getting their own men killed. Mr. Wilkinson went on to say. that surprise was the greatest danger against which we had to guard. This surprise in our case cannot be guarded against entirely by any Navy; that is an impossibility. It depends entirely upon the attitude of mind of the governing "heads," not the governing "class," towards what is fair in war and what is not. Is there such a limitation as a limitation of treachery to be considered in war? You. cannot conceivably guard against treachery, and what we call treachery on the part of the enemy in war is invariably perfectly fair and reasonable on our part when we succeed. IVhen Napoleon seized the bridges over the Danube at Vienna by one of the very meanest tricks ever played, the enemy, who were beaten, complained very bitterly of the infraction of the rules of war, but the. French thought it was defensible, and they have written books to prove it. We can never quite see in advance what view our enemy may take of this vital problem. It really comes to what is fair. in business competition. When two business firms, not of the very highest standing, say, are fighting for very existence, where do they draw a line as to what is fair and what is not? Supposing you were to remove the power of the law backed by the police in the case of such competition, where would the busincss firms stop? $\cdots$ It is a difficult ethical problem to solve, but I think there are many cases one reads of in newspapers where the code of honour has not been quite the same as one would expect from a British Government trusting to the honour of its ncighbouring nations. That is where one of the. chief dangers of surprise comes in, and the easiest way of securing a surprise which for the time being would paralyse us would be undoubtedly to create a gold panic on the London market twenty-four hours before the declaration of hostilities. It is quite impossible for me to say how much gold is held by us in reserve for foreign countries $\rightarrow$ Sir Felix Schuster knows all these details far better than I do - but it amounts, I think, to about 25 per cent. of the total gold reserve of the country, and the sudden presentation of a demand for gold to that amount would, I imagine, throw this country into a state compared to which Overend and Gurney's failure was perfect child's-play. Follow that up for a moment. From that would result an absolute breakdown of credit for the time being. That means that a single sovereign in gold would not support the superstructure of credit which it at present supports. I do not know what the ratio now is exactly, what the amount of credit trade done in a day is to the amount of gold which changes hands; but I believe it is about I per cent. Assume that the consequence 
of such a slock to credit would be that the sovereign only did one-fifth the work it did before, the shrinkage would break down every business in London to the ground. Then, because there was this shrinkage of credit, the outcry for gold would be greater than ever, and all the hoarding instincts which exist in all classes more or less, but more particularly in the less intelligent class of people, would revive, and the money would disappear into stockings, up chimneys, and into the usual places where troops used to look for it in the days when looting was common. We can never solve the question absolutely, but we can at least palliate it in the following manner: Can we supply or devise a magnet which would be sufficiently powerful to draw this gold out of its hiding place? There would be always approximately the same amount of gold in England, because merely as a matter of military expediency we should not allow the actual gold coins to leave the country. It might be paid out of the till in the bank when the bills were presented, but I fancy it would never embark on board a ship, because it would be taken charge of by force majeurc on its way to the docks by the Government. IVe could not afford to allow that gold to go, owing to military expediency, and expediency is the only law in this case. Therefore, the same amount of gold would be always in the country, and the problem is to make that gold do as much work as possible in a given time. It seems to me on that line we can at least arrive at the solution. All ordinary securities-the securities which the barks hold in addition to their bullion-could not be realised in time of war; for the simple reason that nobody would have any money to pay for them. Nobody will buy what they do not need, and there is only one thing they absolutely nced in time of war, and that is food. I think Major Stewart. Murray has said that nothing ever came out of discussions started in this Institution except bluc-books. A few years ago Major Stewart Murray.himself read a paper opening a discussion in this Institution which led to a Royal Commission on the food question, I happen to know, entirely through his exertions. That blue-book on the food supply in war time has had very far-reaching consequences indeed, because it at least shows how we can maintain in this country a sccurity which will be readily realisable in war-time and realisable for gold. When that Food Commission reported, amongst one of its recommendations was a recommendation that we should store food in Manchester in bulk. If you only insist on having gold for your food you will always draw the gold out of people's pockets. Is far as that Committee went, the only kind of food they contemplated was heavy grains, which are very bulky and very difficult to store; but since that time we have gone so far scientifically that it is possible now to preserve food, condensed, with all its nutritive qualities, and keep it ten years or upwards without any loss of those qualities. You can store about a million of rations in a cube of ten feet. If you put down great masses of food of all sorts and kinds-grain and otherwise-the men who hold that would be perfectly certain to draw gold out of people's pockets or wherever it was, and my contention, that something might be done in that way, is based on the fact that in the old days it happens to be exactly what Frederick the Great really did in all the sieges, or what he directed his commanders to do in all the sieges in which his troops were concerned. He said: "As soon as the enemy appears in the vicinity, send round and collect the principal merchants at your office and invite them to lend you all the money they have got in their possession, pointing out that there will be a very large outlay on the labourers and the troops in wages for the work done on the fortifications, and in a very short time all that money would be back 
in the merchants' pockets, because the people must buy their food and pass the money over the counter in order to get the food out. When you have exhausted that supply of money and the siege is going on, you again send for the merchants and borrow the moncy over again, and so you go on; the moncy is circulated round and round, the same coins over and over again." He finished his letter by saying: "And when I come and relieve you I will see the bills are paid." Frederick the Great's word wies so good at that time that he always succeeded in getting the money, and I think the English Government's word is quite as good, and the situation is analagrous. If we talse up the problem in the same way we shall be equally able to borrow all the money we want and keep it circulating round and round, doing its work over and over, again, instead of seeing it hoarded in the stockings my friend has spolien of.

T. Miller Maguire; M.A., LL.D. (Barrister-at-Law, Inner Temple) :I am very loth indeed to interfere in a discussion presided over by a gentleman of the highest eminence in finance and inaugurated by a gentleman of such great authority, one whose books I have read since I was a schoolboy; but I think you will admit that the discussion has somewhat run away from the gold reserve, and that being so, I think 1 am justified in following the remarks of some of the speakers. I quite admit the great value of a gold reserve, whether it be the reserve of an individual or a nation, and I also admit the great value of credit. But you can get credit without gold, and be just as happy and prosperous without either, at least so history teaches me. Mr. Spenser W'illinson refers to Clausewitz's works. I have read them again and again, but $I$ am certain 1 shall never read them again, if $I$ can help it. His authority is not to be taken as infallible in any sense of the word. My friend Mr. Spenser Wilkinson almost proved this statement by his distinction between "limited" and "unlimited" wars and dynastic and national wars. Clausewitz is discredited even in Germany. $I$ advise Colonel Maude to read Von Cammerer and Moltke; but I will not trouble you with much discussion as to which authority is the better. We can learn just as much about credit and reserves of gold from our own history as from German history. One thing is perfectly clear, that since the year 1/93 many a State has entered upon a war, conducted a war, and won battles and employed many myriads of men in war, with very little credit and practically no gold. Colonel Maude does not agree with that statement, and therefore I must prove it. What credit had the French Republic in 1794? What was the value of its gold reserve in 1794? What was the value of all the gold in the French Exchequer in I795? Sir Robert Giffen knows those things better than I do. He knows all about the depreciation of "Mandates" and "Assignats." The French Republicans, like the Huns and Goths, being a new Power of a new species, went forth to conquer, and carried the banner of their Republic and afterwards of their Empire, from the Rhine to Moscow, and through the Southern peninsulas and to the Baltic, based on lack of credit and living on their neighbours! Is not that so? Did not Napoleon "make war support war," just like Mongols and Turks? Is it not so? History, then, is read by different people manifestly in a different way. It is like political economy, which we are now told nobody can understand, or like texts in theology, which not only nobody can understand, but about the interpretations whereof people kill one another. But let us come to another nation. We will take England. What about England in the years 1795 to 1819 ? How much gold was paid in exchange for a $£_{5}$ note then? 1 . thought it was then penal in England to pay in gold; I thought a banker if he 
changed a note for $\oint_{55}$ would be punished. I speak under your correction, Sir Felix; am I right?

\section{Sir Fel.ix Schuster :- "Quite right."}

T. MILler Miaguire: $-\lambda$. banker was punished for changing a $E_{5}$ note on Trafalgar. Day, 1805 , and yet we cannot do without gold! We lought from 1797 to 1 S15, when it wins penal to pay money in gold. We spent during that time some 700 imillions sterling in war; we conquered Napoleon; we maintained fleets on every. sea. When we paid no gold in England we procured specie to pay the Spanish muleteers ( $1 \mathrm{~S}_{12}$ ), and, if I am not mistaken, in 1813 we absolutely paid .13 millions sterling in gold to Germans and other nations to waken them up and to pay their soldiers to fight against Napoleon; and yet we cannot live without gold! Of course we can live without gold. I come to a greater example still. I suppose some of the non-commercial gentlemen here have heard of Greenbacks. You, Sir, know perfectly well what they were, and perhaps some of your colleagues in finance know better than you do, because I daresay there are plenty of Greenbacks still knocking about unchanged in their coffers. I linow the lecturer has heard of them and seen them plenty of times. The United States Government in 1862 and 1863 was being beaten in every battle, and after the hattles of Fredericlisburg and Chancellorville its credit was reduced to such a low ebb that the poor Irish peasant girls who were sent money from their sweethearts across the Atlantic went to the banks thinking they had twenty dollars and found that they had only got ten really. Is that so, Sir?

\section{The Chairman :-_Very likely."}

T. MILLER MaguiRe :-I am absolutely right, I think! Very good. I was told the other night by a new-fangled professor of political economy that the old political economy had gone to Saturn, and that Adam Smith and Mill and Say and other teachers of my youth are not worth a guinea all told. If so, the lecturer and students like myself wasted money and time in our boyhood very foolishly. But is all political economy gone to Saturn? Are Goschen and his Exchanges- "Forcign Exchanges"-gone to Saturn? Do you still believe in Goschen's "Exchanges," Sir? You do? Good! But Goschen proves in his "Exchanges" that in America, merchants could scarcely get any gold (1862-3) except at the most tcrrible rate of exchange premium. What did the United States do? Did they go crying that they had no credit, and that they must burst? Not they! They fought more vigorously to re-establish their credit. They fought and lost about $15^{\circ}, 000$ men and added $f_{500,000,000}$ to the national debt in the interval between the time when Greenbacks were discredited (December, 1862) and the end of the war (April, IS65). I think I have said cnough to put a very heavy onus probandi on people who believe it is the rich nations and the gold reserve nations that win battles. It is the men who win battles, and not the purse. How much money had Frederick the Great, 1757-1760? It is poor nations that win, and not the rich nations that win. Which was the richer and more numerous State with most money reserves in 1870 , France or Germany? Which.won? The nations that deny themselves, win; it is not the luxurious nations that win. I am supported by an illustrious writer, renowned in connection with all points of wisdom, Lord Bacon. Lord Bacon's authority must be accepted. He is a better philosopher and politician than any two Party Cabinets put together. He was a political sage and seer; not a mere windbag of the hour. He lived in the glorious 
days of great bitzabeth, when the English werc men, and not merely Iniserable shibboleth pronouncers and partisan sophists, such as $I$ saw and heard in Peckham on both sides a few evenings ago. Lord Bacon declared in his Essay on "The True Greatness of Kingdoms and Estates": "Ncither is money the sinews of war (as it is trivially said) when the sinew's of men's arms in base and effeminate people are failing: for Solon said well to Crœsus (when in ostentation he showed him his gold): 'Sir, if any other come that hath better iron; he will be master of all this gold.'" I entirely agree with the statement about the necessity for a gold reserve; but this lecture only proves to me in what a terribly, serious condition the whole of modern humanity must be. Reflect carefully on the terrible statements on page 2 of the printed matter supplied. The lecturer dwells on the very serious consequences of the financial dislocation in various recent wars, though in not one of those discussed was our nation, "which is the very citadel of the modern financial system," engaged. He very eloquently emphasiscs the fact that in addition to the other evils of great wars-" "the exhaustion of resources-with loss of life, disease and misery which would remain what they have already beenthere would be new and formidable evils resulting from the breakdown of the international system of credit." Verily our financial whistle is a very costly instrument in time of peace, and always out of tune in time of war. It never could lead any army or race to Glory and Prosperity. I have always held that our niodern civilisation is a farce and a fraud, and in all probability likely to be the curse of the future of the European and Imerican races. It develops credit and capitalisation and tramples on the souls and minds and bodies of humanity. It does not develop manhood, otherwise this part of the lecture could never have been written. The lecturer is speaking of the possibility of war with two Powers. IVe have often gone to war against several Powers, as in 1807 , when we were practically at war with all Europe, immediately after the peace at Tilsit. Here is what one of the best authorities in Europe (the learned lecturer) says: "Such a war (i.e., with two Powers), it seems to me, would bring upon us as well as upon the whole community of civilised States, to which the system of International credit extends, QUITE UNPRECEDENTED CALAMITIES AND DANGERS."' In other words, not because we are decadent merely, not because we cannot fight, not because we are badly armed, not because we have bad generals, not because of any of the causes of failure recorded in the annals of history, but simply because we are living on a false and unnatural basis of this wretched kind in this debasing modern civilisation--a basis of credit which is taking the spirit of manhood out of humanity. I could go on for an hour on this point, but I must give time for other speakers, after having made a small attempt to set an example of loquacity to them. I conclude by heartily thanking Sir Robert Giffen for his most instructive information and his sound advice to our temporising rulers to pay some heed to the principles of statesmanship; and, as to the gold reserve and finance, as well as to the other questions which have been discussed, "to take some thought for to-morrow."

Lieutenant Carlyov Bellairs, M.P. (late Royal Navy) :-1 have only had a hurried glance at the paper. as I was detained by other duties; but I understand the proposition of the paper is a comparatively simple one : to add ten millions to our banking reserve. In other words, I take it Sir

1The capitals are mine.-T.M.MI. 
Robert Giffen thoroughly holds with Mr. Tierney : that if we have a strong Navy and a full Exchequer we can defy the world. I think that is probably the background of the proposition, and it is one I hold very strongly myself. But $I$ do not at all agree with introducing into the discussion of papers like this all the fads like food supply and various other things which are always being aired in this Institution by certain speakers. Looking back over the period to which the last speaker has referred, I think he left out 1825 , which was a time when there was a panic over the bank reserve. The reserves were depleted about 8 millions, and the Government hiad to interfere. Then we come to the Overend and Gurney panic, which was so great that the bank reserve in one day went down 50 per cent., and the Government had to send circulars to every Embassy in Europe in order to allay anxiety in all the European countries with regard to the British financial position. That shows with what grave anxiety the Government regarded the position. Dr. Miller Maguire also referred to 1797; the effect of the banking crisis in that year, when the reserves were depleted to such an extent that there were only $1 \frac{1}{2}$ millions left. It was known there was going to be a further run or the bank on a Monday, and the Privy Council was summoned on the Sunday, and the suspension of specie payment was decreed on the Sunday to meet the situation. The fact of the bank reserves being so depleted and the suspension of specie payment for twenty years undoubtedly made the war highly unpopular, and that shows the importance to some extent of having good bank reserves. Wages suffered through being paid in paper, and I remember reading in Archdeacon Vilberforce's "Recollections" that the war had become highly unpopular in 1797. The position of the country at that time was one of grave anxiety. IVe were threatened with invasions, we had mutiny in our fleet, we had evacuated the Mediterranean, and although that year we won the battle of St. Vincent in February and the battle of Camperdown in August, it did not allay the public anxiety sufficiently to restore our financial credit. The battle of the Nile came the next year, 1798 . I think it all goes to show that it is a wise precaution somewhat to increase the banking reserves in this country which have been built up on a peace basis. The whole thing is organised on a peace basis, for we have had no anxiety in regard to our naval position for practically a hundred years, since Trafalgar. After that battle all anxiety was completely allayed, and insurance rates tumbled down 18 per cent. immediately afterwards, and remained down, and we never had any more anxiety as to our naval position. We have built up this credit system on practically a hundred years of peace. There is no doubt that we are now about to engage in a maritime rivalry, in which we may sce great Europcan wars, and in which it may be well to take stock of the situation, as Sir Robert Giffen suggests, and work with a higher bank reserve than we have been in the habit of doing for the last fifty years.

Sir Robert Giffes, in reply, said :-I hope I may be excused for not saying mucli in reply, because I am not quite sure that $I$ heard all that the speakers have had to say. To some extent I find myself very much in agreement with some of them, as to the importance of the different topics upon which they insist; but it seems to me, especially with such questions as the importance of the food supply in time of war, that some of the topics were a little away from my subject. The importance of all these different things is not to be questioned, but it is perhaps a mistake to run any of those topics one against the other. My feeling is that we have to prepare ourseives in many unexpected directions if there is a 
liability to wars of the kind that have been described, and for that reason I do not wish to enter upon anything which would appear like a controversy as to the relative.importance of the different questions. I should like to make one remark with reference to Colonel Mlaude's suggestion, that in the event of a war or the threatening of war ne ought to prohibit the export of gold, and that that would be of assistance to us in the time of emergency. This is a very old idea. It was what was done practically in 1797, when the Bank of England was restricted from paying in specie. The result was one which I hope we should all wish to avoid, because we had inconvertible paper in this country, not only for a short time, but for twenty years, with many incidental evils and great difficulty indecd in returning to a proper basis. That is the sort of thing we ought to avoid. The mischief that might arise now from anything like a restriction of specie payments or from any measure like the Government prohibiting the export of gold, would probably be in proportion much greater than it was in 1797, or the twenty years that followed. England has become nuch more important as a bullion market since then, and of course to prohibit the export of gold would be practically a prohibition of the trade in bullion, which is not a matter by which we should be advantaged. It is to avoid these things if possible and to avoid the danger of inconvertible paper that the Government ought to sce to it in time of peace that the reserve of gold is ample for the contingency of war. That was the whole point of the paper. One remark of Mr. Bellairs, I think, perhaps rather exaggerated: what happened in 1866 . I happen to know something of the circumstances of the circular which the Forcign Office sent round in 1866, trying to explain away the crisis of that year, and I think perhaps it ought to be mentioncd that the precedent was rather a dangerous one which Lord Clarendon set at that time, and the-City authorities were by no means agrced as to the expediency or the necessity of that circular. Still, it is quite true, as Mr. Bellairs has pointed out, that the excitement of that time was very great, and the circular showed what commotion there might be in Government circles when anything like a panic takes place. The danger of a bank panic, thercfore, when a great war is threatened is one to which no doubt any Government would give its mind-too late, as I think, because now is the time when we ought to prepare.

The Chairman (Sir Felix Schuster):-I have now much pleasure in moving a vote of thanks to the reader of this paper-a paper which is of considerable importance, and to which we have all listened with great interest, and one which $I$ hope will have its influence, especially with our rulers, because, in spite of what has been said this afternoon, when civilians speak on these matters they are not always listened to by the authorities with that readiness which we think the importance of the subject deserves. I think the question of our gold supply is one which our authorities at the Treasury and at the VVar Office ought to bear in mind. After all, it is a question of reserves. You have reserves of ammunition, or at least 1 suppose you have-we understand you have-and reserves of men and guns and horses. ("Not of horses.") Well, we civilians suppose you have, and it is not for me to express an opinion. Anyway, what those of us, who have taken an interest in this subject and have advocated the keeping of larger gold reserves, maintain is, that in case of a sudden outbreals of war with one or two of the great European Powers, you will find that this question would put you in a very serious difficulty indeed. With regard to what Dr. Miller Maguire has observed as to our present 
state of civilisation, I may perhaps be in complete agreement with him, that it might be desirable for all of us to have done with it and return to a different state of society altogether; but we have got it now and we must make the best of what we have got. If you were to carry on your wars with Greenbacks and Assignats, 1 do not think you would get very far. I would remind you that at the time to which he has alluded, when gold payments were suspended-I must refer to the food supply for a moment-I believe that England produced her food supplies at home. . We did not buy our supplies for our people, nor for our troops, nor for our men, abroad; we had not to buy from foreign countries all the raw material used for our manufactures-the manufactures on which our people live. If a war were to break out and the credit system were to break down, if we could not pay in gold what we have undertaken to pay in gold, then we should find that our people would be put into very great distress at a very early moment after the outbreak of hostilities. That is one of the reasons why, I think, this subject is of importance. In reply to Mr. Spenser Wilkinson, I should say yes, of course, we must have an efficient Navy. We cannot do without a Navy to keep the command of the sea; but this difficulty of gold reserve will arise before the first shot in the war is fired. As has been pointed out by Colonel Maude, who referred to business morality-l will not say anything about business morality, because I do not think we need go into that question-I do not know where morality comes in when it comes to a question of your enemy. I think it will be his duty to hurt us wherever he can, and it will be our duty to hurt him wherever we can; and for his own protection he will draw all the gold that he possibly can away from our shores, and try to cripple us in our credit, in our home manufactures, in our industry, and in our International commerce. It will be quite right for him to do so, and it will be for us to see that he cannot. With regard to the paper, there has been one subject mentioned as to prohibiting the shipment of gold. I think we should certainly prohibit the shipment of gold to the enemy. I suppose all commercial transactions with the enemy would come to a standstill. But there are obligations to neutrals also, and those obligations will have to be carried out if the credit of the country is to be maintained, if our International commercial and banking position is to be maintained. I am in general agreement with what Sir Robert Giffen has so rell said. The International credit system is a very intricate system, and cannot be discussed at a meeting like this. The effect of it has never been tried in great European wars; but no doubt a great strain would be put upon it. I thinls perhaps he has to some extent overstated the difficulty, and perhaps he has rather exaggerated the weakness of our credit system. I am convinced that our credit system at home in ordinary times, in peace time, works admirably, and I think that the precautions that have to be taken need not go into such very large figures, and need not be so very costly. I say that for this reason: This country has an immense power of drawing gold from foreign countries. We-are a creditor nation. I belicve our income from foreign investments amounts to something like 120 to 150 millions sterling per annum, which sums we are entitled to draw from foreign countries, and as long as we keep command of the sea we shall draw it from forcign countries, and draw it in gold, or its equivalent. Therefore, the danger is one that would come at the outset; that would come as a surprise; and to guard against such dangers I do not think the amount noed be excessive. We need not go into hundreds of millions. I agree with Mr. Spenser Wilkinson, that perhaps the recommendations Sir Robert Giffen has made are rather moderate. 


\section{NECESSITY OF A WAR CHEST IN THIS COLNTRY.}

I agree that it is only a beginning, and we want to gro further. But still his recommendations go to the root of the matter and carry us some distance. Sir Robert has said that there is no provision for gold payment except the bank reserves in the Bank of England. I do not think that is quite correct. I believe at the Royal Mint a census was taken last July of the gold held in the banks apart from the gold in circulation. The results have not been published yet, and I have no oficial information; but I believe it will be found that the amount so held is considerably over 30 millions-from 32 to 35 millions is the amount estimated to be held by the banks in the United Kingdom, apart from the ordinary coin in circulation, which is estimated at something like so millions. That 30 millions in the bank is really in addition to till money, and is an actual reserve. Then, again, you have the notes in the hands of the banks, and I believe it would be found if a census of those notes were taken that they amount to something very considerable. I am personally persuaded. although I have no figures to go by, that the whole increase in the bank note circulation of the Bank of England since the Bank Charter of 184, , which amounts to about 20 millions, is not in the hands of the public but in the hands of the bankers. These notes are convertible into gold as long as the Bank of England carries out the obligations put upon it by the Act of $184+$. I for one maintain-and I am sorry to say so-that if very serious strain were put upon the bank, and a very great emergency were to arise, I am not quite sure that the payment in gold would be as certain as we like to look upon it. I say that for this reason above all, we advocate that the Bank of England reserves should be strengthened. Conditions have changed very much indeed since 1844 , which was the last time this question was considered by the Legislature. The whole of the conditions of commerce have altered, the volume of trade has increased enormously, our International position has changed enormously; and therefore this question should be considered, not only academically, but really, by those who have it in their power to bring about a modification, if it is found necessary to do so. One important point that has not been touched upon is the question of the Government Savings Banks. You are well aware that the Treasury itself-the Government-carries on the biggest banking business in the whole country. The Savings Banks hold: through the Post Office, about 156 millions; through the Trustee Savings Banks, 53 millions; in deposits from the public, mostly from the working classes, a total of 209 millions. That money is all invested in Consols or Government securities, and there is no cash rescrve held against those deposits; nothing beyond a very small amount of ordinary till money. I think myself, although opinions differ, that the State should keep a considerable reserve in gold against these liabilities. That is not the official view. Only last session the Chancellor of the Exchequer again expressed the opinion in the House of Commons that "the National Debt Commissioners keep such cash reserves as experience shows to be necessary for the requirements of the Savings Banks, that the conditions of the Savings Bank business are so different from those of commercial banking that he was unable to admit any analogy between the two cases in regard to the question of reserves." That is the official view which has been always expressed in the House of Commons. I differ from it altogether. I think in case of a sudden outbreak of war, in the case of our food supplies or supplies of material for our manufacturers not arriving as rapidly as in times of peace, there will be a lack of employment, and it is in that case that the Savings Banks of the people must be encroached upon by the people for their money. To meet such a case, a nucleus of a reserve in gold 
should be formed which would be of great assistance in other matters as well. Then you come to the relations between the State and the Bank of England, which relations are of very considerable importance. As you are aware; the State is indebted to the Bank of England to the extent of eleven millions on which interest is paid, and that debt forms the basis of bank notes. If the State were to pay back eleven millions to the Bank, and the notes were issued against gold and not against credit, then a very great improvement in the position would take place, not at very great cost to the country. As has been said, I shall have an opportunity of further expressing my views on these matters before very long, and I am afraid I have already detained the meeting too long on this occasion, and therefore $I$ ask you once more most cordially to thank Sir Robert Giffen for bringing this matter to your notice to-day. 